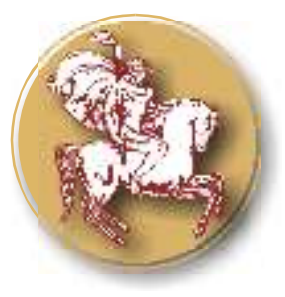

Trakia Journal of Sciences, No 4, pp 310-318, 2020

Copyright (C) 2020 Trakia University

Available online at:

http://www.uni-sz.bg

ISSN 1313-3551 (online)

doi:10.15547/tjs.2020.04.004

Original Contribution

\title{
A COMPARATIVE INVESTIGATION OF METHODS FOR THE DISCOVERY OF HELMINTH EGGS AND COCCIDIA OOCYSTS IN SOIL SAMPLES
}

\author{
A. Ivanov ${ }^{*}$, P. T. Iliev \\ Department of Veterinary Microbiology, Infectious and Parasitic Diseases, Faculty of Veterinary \\ Medicine, Trakia University, Stara Zagora, Bulgaria
}

\begin{abstract}
A comparative investigation of two methods of soil study was performed - a modified by us and a classic flotation method, using standard media and soil. Different flotation solutions and cultures of eggs of Trichuris vulpis, Toxocara canis and Taenia pisisformis and oocysts of Eimeria stiedai were used. A method for use in diagnostic practice is proposed.
\end{abstract}

Key words: Trichuris vulpis, Toxocara canis, Taenia pisisformis eggs; Eimeria stiedai oocysts; methods of soil investigations

\section{INTRODUCTION}

Environmental pollution with organic products is one of the major problems of modern society. Part of these products is forms or stages of the development of pathogens. The examination of soil, water and air for such pathogens is an important point in organizing measures for the prevention and control of certain diseases in animals and humans (1). Many parasitic invasions, including zoonoses, occur after the ingestion of parasitic eggs from the environment. They form invasive parasitic stages, which find favourable conditions and persist for months and years $(2,3)$. Soil is the most common factor for the distribution of these eggs.

In reviewing the scientific literature related to methods for detecting helminth eggs in the soil, we have identified a wide variety of techniques using many variations of flotation solutions (4-7). To conduct a specific study, each author team adopts its own diagnostic method or introduces modifications to an existing one, which suggests differences in the results

\footnotetext{
"Correspondence to: A. Ivanov, Department of Veterinary Microbiology, Infectious and Parasitic Diseases, Faculty of Veterinary medicine, Trakia University, 6000 Stara Zagora, Bulgaria, tel: +359 42699 589, E-mail: andrey1958@abv.bg
}

obtained and inaccuracies in their comparison. The most numerous and the most commonly used methods are for discovering the eggs of Toxocara and Toxascaris spp. in the soil samples, but they also have variations in pretreatments and flotation media (8-13).

Quinn et al. (5) and Santarem et al. (12) carry out comparative diagnostic studies of some flotation media. Zenner et al. (14) attempt to develop a standardized method for detecting eggs of Toxocara canis, Trichuris ovis, Heterakis gallinarum and Eimeria mulardi. Gnani Charitha et al. (15) tested several flotation methods proposed by other authors to prove eggs of Toxocara sp., Ascaris sp., Ancylostoma sp., and Eimeria sp. oocysts in naturally contaminated soil samples. They find that the most sensitive of the methods studied is that of O'Lorcain (9), possibly due to the use of detergents in flotation media.

In the literature, we have not found flotation techniques to be used for the simultaneous detection of nematode and cestode eggs and protozoal oocysts in soil samples. The spread of cestode invasions, and especially those with Taenia spp. in animals and humans poses a serious economic and health risk. Many classic and more modern flotation techniques have indicated that in addition to nematodes, some cestode eggs can be found by them. Therefore, 
we aim to conduct comparative studies of some of the aforementioned methods and to offer diagnostic practice an effective, easy-toimplement method for simultaneous detection of nematode and cestode eggs, and coccidia oocysts in soil samples.

\section{MATERIAL AND METHODS Materials}

- Faecal samples

In order to select suitable, naturally invaded dogs and/or donor cats, 27 yard and hunting dogs and 11 cats from three villages around Stara Zagora town were pre-tested for parasitic invasions. The animals were 6 months to 10 years of age, in satisfactory clinical health and were not separated from their owners. Following the studies, animals producing a sufficient number of helminth eggs were selected for culture preparation.

- Preparation of cultures from helminth eggs and oocysts

After identifying carnivorous donors, we collected their faeces for a specified period in order to obtain sufficient cultures. Samples were processed by the Darling method and the collected eggs were dialyzed against distilled water. In this way, we prepared cultures from eggs of Trichuris vulpis and T. canis. In one dog excreting the Taenia pisiformis proglottids, we collected the gravid proglottids in water and tore them with preparatory needles to release the eggs. The collected eggs were washed twice by centrifugation with water for $5 \mathrm{~min}$ at $500 \mathrm{rpm}$. Due to the inability at this time to detect coccidia oocysts of carnivorous animals, in our experiments we included a culture of sporulated oocysts of Eimeria stiedai available in our protozoological laboratory.

- Mediums used for testing the methods

Quartz sand fraction $0.16 \mathrm{~mm}$ of Quartz Sands Ltd. Sofia was used as a standard medium. We chose quartz sand with small particle sizes $(0.16 \mathrm{~mm}$ in diameter) because of its uniformity and inertness. For the soil medium, we used soil, taken from the site to the laboratory, which was not visited by animals. The soil was sifted through a sieve with $0.5 \mathrm{~cm}$ diameter of holes to remove larger particles and checked using the Dada method (4) for helminth eggs and coccidia oocysts. The soil medium was sterilized in an oven at $200^{\circ} \mathrm{C}$ for 1 hour, and kept in a closed container until including in the experiment.

- Flotation solutions
Four flotation solutions were prepared: a saturated $\mathrm{ZnSO}_{4}$ solution with a relative density (RD) of 1.47 ; saturated $\mathrm{MgSO}_{4}$ solution having $\mathrm{RD}$ of 1.300 ; saturated $\mathrm{NaCl}$ solution, 1.200 RD and $\mathrm{ZnSO}_{4}$ solution, 1.200 $\mathrm{RD}$. The relative density of the solutions was determined and controlled at $20^{\circ} \mathrm{C}$ using a universal hydrometer with a built-in thermometer, and a measuring range of 1.0001.500 .

\section{Tested methods}

- Modified by us method of Zenner et al. (14) $50 \mathrm{~g}$ of medium (soil) sample is mixed with $100 \mathrm{ml}$ of water in a beaker, shaken and allowed to precipitate for $20 \mathrm{sec}$., then filtered through a strainer with apertures of $0.1 \mathrm{~mm}$. The resulting suspension was poured into four tubes of $25 \mathrm{ml}$ and centrifuged for $5 \mathrm{~min}$ at 150 rpm. Note the liquid level in the tubes and pour off the supernatant, and add the flotation solution to the indicated level (up to $100 \mathrm{ml}$ ) on the remaining precipitate by stirring with a glass rod and centrifuging again for $5 \mathrm{~min}$ at $150 \mathrm{rpm}$. We perform the reading on a microscope, preparing from each tube 5 slides with 6 drops each, taken from the surface of the liquid by means of a wire loop $0.5 \mathrm{~cm}$ in diameter.

In the original method of Zenner et al. (14), solutions of $\mathrm{MgSO}_{4}$ and mercuric iodide were used, with a RD of 1.280 and 1.440, respectively. In our study, we replaced them with the ones above.

\section{- Classic flotation technique}

$50 \mathrm{~g}$ sample was mixed with $100 \mathrm{ml}$ flotation solution, stirred and filtered through a $0.1 \mathrm{~mm}$ mesh strainer. The liquid is poured into four conical porcelain pots of $25 \mathrm{ml}$. Wait 30 minutes and read on a microscope, preparing from each pot 3 slides of 6 drops each, taken from the surface of the liquid by means of a $0.5 \mathrm{~cm}$ diameter wire loop.

\section{Test performance}

Prior to the start of the tests from the already prepared cultures, we prepared those with precisely defined concentrations of helminth eggs or coccidia oocysts. Sufficient amounts of 100 eggs or oocysts $/ \mathrm{ml}$ and 500 eggs or oocysts /ml of T. pisiformis, T. canis, T. vulpis and E. stiedai were prepared.

- Direct examination of the sensitivity of the methods without medium

- For the modified by us method of Zenner et al. (14) 
$1 \mathrm{ml}$ of cultures containing 100 eggs or oocysts $/ \mathrm{ml}$ is mixed with $100 \mathrm{ml}$ of tap water. The resulting suspension was poured into 4 tubes of $25 \mathrm{ml}$ and centrifuged for $5 \mathrm{~min}$ at $150 \mathrm{rpm}$. Note the liquid level in the tubes and pour off the supernatant, and add the flotation solution to the indicated level (up to $100 \mathrm{ml}$ ) on the remaining sediment by stirring with a glass rod and centrifuging again for $5 \mathrm{~min}$ at $150 \mathrm{rpm}$. We perform the reading on a microscope, preparing from each tube 5 slides with 6 drops each, taken from the surface of the liquid by means of a wire loop $0.5 \mathrm{~cm}$ in diameter. The study was performed ten times for the four culture types and for the four types of flotation solutions.

\section{-For the classic flotation technique}

$1 \mathrm{ml}$ of cultures containing 100 eggs or oocysts $/ \mathrm{ml}$ were mixed with $100 \mathrm{ml}$ of flotation solution. The liquid is poured into four conical porcelain pots of $25 \mathrm{ml}$. Wait 30 minutes and read on a microscope, preparing from each pot 3 slides of 6 drops each, taken from the surface of the liquid by means of a $0.5 \mathrm{~cm}$ diameter wire loop. The study was performed ten times for the four culture types and for the four types of flotation solutions.

- Investigation of the sensitivity of methods using a standard medium

A total of 320 samples of $50 \mathrm{~g}$ of standard medium (quartz sand) were artificially contaminated with 500 eggs or oocysts from the four cultures prepared. 160 samples of standard contaminated medium were tested by the modified method of Zenner et al. (14), and 160 samples by the classical flotation technique. The study was performed ten times for the four culture types and for the four types of flotation solutions.

- Investigation of the sensitivity of methods using soil medium

A total of 320 samples of $50 \mathrm{~g}$ of the prepared a soil medium were artificially contaminated with 500 eggs or oocysts from the prepared four cultures. 160 samples of contaminated soil were tested by the modified method of Zenner et al. (14), and 160 using the classical flotation technique. The study was performed ten times for the four culture types and for the four types of flotation solutions. The sensitivity of the different flotation solutions and methods was determined based on the percentage of detection and the smallest number of eggs or oocysts found in the soil medium.
- Investigation of the sensitivity of selected methods for the examination of naturally contaminated samples

After collecting, processing and discussing the results obtained, we tested the most sensitive methods on potentially naturally contaminated soil samples. For this purpose, we have taken 50 samples of soil or sand from pre-selected places in Stara Zagora town with the highest probability of contamination - lawns in places where domestic, and stray dogs and cats stroll, sandpits from playgrounds, parks and gardens, places between buildings, and more.

All microscopic examinations and measurements were performed by Axioscop ${ }^{\circledR}$ Zeiss, Jena.

\section{RESULTS}

- Direct examination of the sensitivity of the methods without medium

In the direct examination, the sensitivity of the two methods with a culture concentration of 100 eggs or oocysts $/ \mathrm{ml}$, we obtained the following results shown in Table 1.

For $T$. canis egg culture, the highest sensitivity according to the method of Zenner et al. (14) was obtained when working with the $\mathrm{MgSO}_{4}$ flotation solution (RD 1.300) - 28\%. We found low sensitivity of the flotation solution of $\mathrm{ZnSO}_{4}$ (RD 1.470) - 20\%, and lower sensitivity of $\mathrm{ZnSO}_{4}(\mathrm{RD} 1.200)-10 \%$ and $\mathrm{NaCl}$ (RD 1.200) - 8\%.

In the study of the same culture using the classic flotation technique, the highest sensitivity was obtained when working with the $\mathrm{ZnSO}_{4}$ flotation solution (RD 1.470) - 86\%. Low sensitivity was found for the flotation solution of $\mathrm{MgSO}_{4}(\mathrm{RD} 1.300)-59 \%$, and lower sensitivity of $\mathrm{ZnSO}_{4}$ (RD 1.200) - 44\% and $\mathrm{NaCl}$ (RD 1.200) - 39\%.

For the culture with $T$. vulpis eggs, the highest sensitivity according to the method of Zenner et al. (14) was obtained when working with the $\mathrm{MgSO}_{4}$ flotation solution (RD 1.300) - 19\%. Low sensitivity was found with the flotation solution of $\mathrm{ZnSO}_{4}$ (RD 1.470) - 14\%, and lower sensitivity of $\mathrm{ZnSO}_{4}$ (RD 1.200) - 7\% and $\mathrm{NaCl}(\mathrm{RD} 1.200)-5 \%$.

When studying the same culture using the classic flotation technique, the highest sensitivity was obtained when working with the $\mathrm{ZnSO}_{4}$ flotation solution (RD 1.470) $55 \%$. Low sensitivity was found with the $\mathrm{MgSO}_{4}$ flotation solution (RD 1.300) - 40\%, and lower sensitivity of $\mathrm{ZnSO}_{4}(\mathrm{RD} 1.200)$ $31 \%$ and $\mathrm{NaCl}$ (RD 1.200) - $24 \%$. 
For the T. pisiformis egg culture, the highest sensitivity according to the method of Zenner et al. (14) was obtained when working with the $\mathrm{ZnSO}_{4}$ flotation solution (RD 1.470) - $1.9 \%$. Low sensitivity was found for the flotation solution of $\mathrm{ZnSO}_{4}$ (RD 1.200) - $0.7 \%$, and lower sensitivity of $\mathrm{MgSO}_{4}$ (RD 1.300) - $0.2 \%$ and $\mathrm{NaCl}(\mathrm{RD} 1.200)-0.2 \%$.

In the study of the same culture using the classic flotation technique, the highest sensitivity was obtained when working with the $\mathrm{ZnSO}_{4}$ flotation solution (RD 1.470) $7.8 \%$. Low sensitivity was found for the flotation solution of $\mathrm{ZnSO}_{4}$ (RD 1.200) - 7.2\%, and lower sensitivity of $\mathrm{MgSO}_{4}$ (RD 1.300) $0.7 \%$ and $\mathrm{NaCl}$ (RD 1.200) - 2.4\%.
For the culture with E. stiedai oocysts, the highest sensitivity by the method of Zenner et al. (14) was obtained when working with the $\mathrm{ZnSO}_{4}$ flotation solution (RD 1.470) - 3\%. Low sensitivity was found for the flotation solution of $\mathrm{ZnSO}_{4}$ (RD 1.200) - 2\%, and the similarity was found for the sensitivity of $\mathrm{MgSO}_{4}$ (RD 1.300) - $1.8 \%$ and $\mathrm{NaCl}$ (RD $1.200)-1.9 \%$.

In the study of the same culture using the classic flotation technique, the highest sensitivity was obtained when working with the $\mathrm{ZnSO}_{4}$ flotation solution (RD 1.470) $31.4 \%$. We found a low sensitivity of the flotation solution of $\mathrm{ZnSO}_{4}$ (RD 1.200) - 15\%, and lower sensitivity of $\mathrm{MgSO}_{4}$ (RD 1.300) $7.1 \%$ and $\mathrm{NaCl}$ (RD 1.200) - $12.4 \%$.

Table 1. Direct examination of the sensitivity of the methods without medium (in cultures of 100 eggs or oocysts $/ \mathrm{ml}$ )

\begin{tabular}{|c|c|c|c|c|c|c|c|}
\hline$\frac{\vec{g}}{\sum_{0}^{e}}$ & $\begin{array}{c}\text { Culture } \\
\text { of eggs or } \\
\text { oocysts }\end{array}$ & $\begin{array}{l}\text { Flotation } \\
\text { solution and } \\
\text { relative } \\
\text { density }\end{array}$ & $\begin{array}{l}\text { Sensitivity } \\
\text { in \% }\end{array}$ & 莺 & $\begin{array}{c}\text { Culture } \\
\text { of eggs or } \\
\text { oocysts }\end{array}$ & $\begin{array}{c}\text { Flotation } \\
\text { solution and } \\
\text { relative } \\
\text { density }\end{array}$ & $\begin{array}{l}\text { Sensitivity } \\
\text { in } \%\end{array}$ \\
\hline \multirow{16}{*}{ 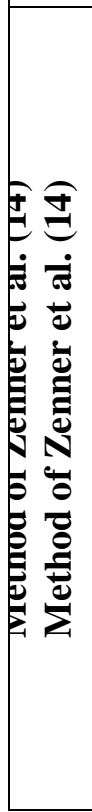 } & \multirow{4}{*}{$\begin{array}{c}\text { Toxocara } \\
\text { canis }\end{array}$} & $\mathrm{NaCl} 1.200$ & 8 & \multirow{16}{*}{ 苞 } & \multirow{4}{*}{$\begin{array}{c}\text { Toxocara } \\
\text { canis }\end{array}$} & $\mathrm{NaCl} 1.200$ & 39 \\
\hline & & $\mathrm{MgSO}_{4} 1.300$ & $28 *$ & & & $\mathrm{MgSO}_{4} 1.300$ & 59 \\
\hline & & $\mathrm{ZnSO}_{4} 1.200$ & 10 & & & $\mathrm{ZnSO}_{4} 1.200$ & 44 \\
\hline & & $\mathrm{ZnSO}_{4} 1.470$ & 20 & & & $\mathrm{ZnSO}_{4} 1.470$ & $86 *$ \\
\hline & \multirow{4}{*}{$\begin{array}{c}\text { Trichuris } \\
\text { vulpis }\end{array}$} & $\mathrm{NaCl} 1.200$ & 5 & & \multirow{4}{*}{$\begin{array}{c}\text { Trichuris } \\
\text { vulpis }\end{array}$} & $\mathrm{NaCl} 1.200$ & 24 \\
\hline & & $\mathrm{MgSO}_{4} 1.300$ & 19* & & & $\mathrm{MgSO}_{4} 1.300$ & 40 \\
\hline & & $\mathrm{ZnSO}_{4} 1.200$ & 7 & & & $\mathrm{ZnSO}_{4} 1.200$ & 31 \\
\hline & & $\mathrm{ZnSO}_{4} 1.470$ & 14 & & & $\mathrm{ZnSO}_{4} 1.470$ & $55 *$ \\
\hline & \multirow{4}{*}{$\begin{array}{c}\text { Taenia } \\
\text { pisiformis }\end{array}$} & $\mathrm{NaCl} 1.200$ & 0.2 & & \multirow{4}{*}{$\begin{array}{c}\text { Taenia } \\
\text { pisiformis }\end{array}$} & $\mathrm{NaCl} 1.200$ & 2.4 \\
\hline & & $\mathrm{MgSO}_{4} 1.300$ & 0.2 & & & $\mathrm{MgSO}_{4} 1.300$ & 0.7 \\
\hline & & $\mathrm{ZnSO}_{4} 1.200$ & 0.7 & & & $\mathrm{ZnSO}_{4} 1.200$ & 7.2 \\
\hline & & $\mathrm{ZnSO}_{4} 1.470$ & 1.9* & & & $\mathrm{ZnSO}_{4} 1.470$ & $7.8^{*}$ \\
\hline & \multirow{4}{*}{$\begin{array}{c}\text { Eimeria } \\
\text { stiedai }\end{array}$} & $\mathrm{NaCl} 1.200$ & 1.9 & & \multirow{4}{*}{$\begin{array}{c}\text { Eimeria } \\
\text { stiedai }\end{array}$} & $\mathrm{NaCl} 1.200$ & 12.4 \\
\hline & & $\mathrm{MgSO}_{4} 1.300$ & 1.8 & & & $\mathrm{MgSO}_{4} 1.300$ & 7.1 \\
\hline & & $\mathrm{ZnSO}_{4} 1.200$ & 2 & & & $\mathrm{ZnSO}_{4} 1.200$ & 15 \\
\hline & & $\mathrm{ZnSO}_{4} 1.470$ & $3 *$ & & & $\mathrm{ZnSO}_{4} 1.470$ & 31.4* \\
\hline
\end{tabular}

*highest sensitivity for the culture type

- Investigation of the sensitivity of the methods using a standard medium

In testing the sensitivity of the two methods by standard medium (quartz sand), with a culture concentration of 500 eggs or oocysts $/ \mathrm{ml}$ the results are shown in Table 2.

For the $T$. canis egg culture, the highest sensitivity according to the method of Zenner et al. (14) was obtained when working with the $\mathrm{MgSO}_{4}$ flotation solution (RD 1.300) - 8.4\%. Low sensitivity was found for the flotation solution of $\mathrm{ZnSO}_{4}$ (RD 1.470) - 8\%, and lower sensitivity of $\mathrm{ZnSO}_{4}$ (RD 1.200) - $1.2 \%$ and $\mathrm{NaCl}$ (RD 1.200) - 2.4\%.

In the study of the same culture using the classic flotation technique, the highest sensitivity was obtained when working with the $\mathrm{ZnSO}_{4}$ flotation solution (RD 1.470) $33.2 \%$. We found low sensitivity of the $\mathrm{MgSO}_{4}$ flotation solution (RD 1.300) - 26.4\%, $\mathrm{ZnSO}_{4}$ (RD 1.200) - 22.4\% and $\mathrm{NaCl}(\mathrm{RD} 1.200)-$ $23.4 \%$. 
For the T. vulpis egg culture, the highest sensitivity according to the method of Zenner et al. (14) was obtained when working with the $\mathrm{ZnSO}_{4}$ flotation solution (RD 1.470) - 2.8\%. We found low sensitivity of the $\mathrm{MgSO}_{4}$ flotation solution (RD 1.300) - $2 \%$, and lower was sensitivity of $\mathrm{ZnSO}_{4}$ (RD 1.200) - $1.2 \%$ and $\mathrm{NaCl}$ (RD 1.200) - $0.2 \%$.

When studying the same culture using the classic flotation technique, the highest sensitivity was obtained when working with the $\mathrm{ZnSO}_{4}$ flotation solution (RD 1.470) $19.8 \%$. We found low sensitivity of the flotation solution of $\mathrm{ZnSO} 4$ (RD 1.200) $6.4 \%$, and lower sensitivity of $\mathrm{MgSO}_{4}$ (RD $1.300)-3.6 \%$ and $\mathrm{NaCl}$ (RD 1.200) - 3\%.

For the T. pisiformis egg culture, the highest sensitivity according to the method of Zenner et al. (14) was obtained when working with the $\mathrm{ZnSO}_{4}$ flotation solution (RD 1.470) - 7.8\%. We found a low sensitivity of the flotation solution of $\mathrm{ZnSO}_{4}$ (RD 1.200) - 1\%, and lower sensitivity of $\mathrm{MgSO}_{4}$ (RD 1.300) - $0.6 \%$ and $\mathrm{NaCl}$ (RD 1.200) - $0.6 \%$.
In the study of the same culture using the classic flotation technique, the highest sensitivity was obtained when working with the $\mathrm{ZnSO}_{4}$ flotation solution (RD 1.470) $11 \%$. Low sensitivity was found for the flotation solution of $\mathrm{ZnSO}_{4}$ (RD 1.200) $10.2 \%$, and lower sensitivity of $\mathrm{MgSO}_{4}$ (RD 1.300 ) $-1 \%$ and $\mathrm{NaCl}$ (RD 1.200) - 3.6\%.

For the culture with E. stiedai oocysts, the highest sensitivity according to the method of Zenner et al. (14) was obtained when working with the $\mathrm{ZnSO}_{4}$ flotation solution (RD 1.470) $14.2 \%$. Low sensitivity was found for the flotation solution of $\mathrm{ZnSO}_{4}$ (RD 1.200) - 8.8\%, and the similarity was found for sensitivity of $\mathrm{MgSO}_{4}(\mathrm{RD} 1.300)-7.2 \%$ and $\mathrm{NaCl}$ (RD 1.200) $-7.8 \%$.

In the study of the same culture using the classic flotation technique, the highest sensitivity was obtained when working with the $\mathrm{ZnSO}_{4}$ flotation solution (RD 1.470) $47.2 \%$. We found a low sensitivity of the flotation solution of $\mathrm{ZnSO}_{4}$ (RD 1.200) $27.6 \%$, and lower sensitivity of $\mathrm{MgSO}_{4}$ (RD $1.300)-10.6 \%$ and $\mathrm{NaCl}$ (RD 1.200) - $18.6 \%$.

Table 2. Investigation of the sensitivity of the methods using a standard medium (in cultures with 500 eggs or oocysts $/ \mathrm{ml}$ )

\begin{tabular}{|c|c|c|c|c|c|c|c|}
\hline 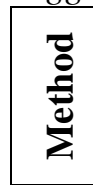 & $\begin{array}{l}\text { Culture } \\
\text { of eggs or } \\
\text { oocysts }\end{array}$ & $\begin{array}{c}\text { Flotation } \\
\text { solution and } \\
\text { relative } \\
\text { density }\end{array}$ & $\begin{array}{l}\text { Sensitivity } \\
\text { in \% }\end{array}$ & 窇 & $\begin{array}{l}\text { Culture } \\
\text { of eggs or } \\
\text { oocysts }\end{array}$ & $\begin{array}{l}\text { Flotation } \\
\text { solution and } \\
\text { relative } \\
\text { density }\end{array}$ & $\begin{array}{c}\text { Sensitivity } \\
\text { in } \%\end{array}$ \\
\hline \multirow{16}{*}{ 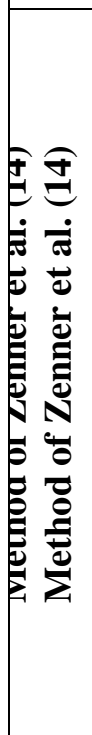 } & \multirow{4}{*}{$\begin{array}{c}\text { Toxocara } \\
\text { canis }\end{array}$} & $\mathrm{NaCl} 1.200$ & 2.4 & \multirow{16}{*}{$\stackrel{\mathscr{g}}{\mathscr{g}}$} & \multirow{4}{*}{$\begin{array}{c}\text { Toxocara } \\
\text { canis }\end{array}$} & $\mathrm{NaCl} 1.200$ & 23.4 \\
\hline & & $\mathrm{MgSO}_{4} 1.300$ & $8.4^{*}$ & & & $\mathrm{MgSO}_{4} 1.300$ & 26.4 \\
\hline & & $\mathrm{ZnSO}_{4} 1.200$ & 1.2 & & & $\mathrm{ZnSO}_{4} 1.200$ & 22.4 \\
\hline & & $\mathrm{ZnSO}_{4} 1.470$ & 8 & & & $\mathrm{ZnSO}_{4} 1.470$ & 33.2* \\
\hline & \multirow{4}{*}{$\begin{array}{c}\text { Trichuris } \\
\text { vulpis }\end{array}$} & $\mathrm{NaCl} 1.200$ & 0.2 & & \multirow{4}{*}{$\begin{array}{c}\text { Trichuris } \\
\text { vulpis }\end{array}$} & $\mathrm{NaCl} 1.200$ & 2.8 \\
\hline & & $\mathrm{MgSO}_{4} 1.300$ & 2 & & & $\mathrm{MgSO}_{4} 1.300$ & 3.6 \\
\hline & & $\mathrm{ZnSO}_{4} 1.200$ & 1.2 & & & $\mathrm{ZnSO}_{4} 1.200$ & 6.2 \\
\hline & & $\mathrm{ZnSO}_{4} 1.470$ & $2.8^{*}$ & & & $\mathrm{ZnSO}_{4} 1.470$ & $19.8^{*}$ \\
\hline & \multirow{4}{*}{$\begin{array}{c}\text { Taenia } \\
\text { pisiformis }\end{array}$} & $\mathrm{NaCl} 1.200$ & 0.6 & & \multirow{4}{*}{$\begin{array}{c}\text { Taenia } \\
\text { pisiformis }\end{array}$} & $\mathrm{NaCl} 1.200$ & 3.6 \\
\hline & & $\mathrm{MgSO}_{4} 1.300$ & 0.6 & & & $\mathrm{MgSO}_{4} 1.300$ & 1 \\
\hline & & $\mathrm{ZnSO}_{4} 1.200$ & 1 & & & $\mathrm{ZnSO}_{4} 1.200$ & 10.2 \\
\hline & & $\mathrm{ZnSO}_{4} 1.470$ & 7.8* & & & $\mathrm{ZnSO}_{4} 1.470$ & $11 *$ \\
\hline & \multirow{4}{*}{$\begin{array}{c}\text { Eimeria } \\
\text { stiedai }\end{array}$} & $\mathrm{NaCl} 1.200$ & 7.8 & & \multirow{4}{*}{$\begin{array}{c}\text { Eimeria } \\
\text { stiedai }\end{array}$} & $\mathrm{NaCl} 1.200$ & 18.6 \\
\hline & & $\mathrm{MgSO}_{4} 1.300$ & 7.2 & & & $\mathrm{MgSO}_{4} 1.300$ & 10.6 \\
\hline & & $\mathrm{ZnSO}_{4} 1.200$ & 8.8 & & & $\mathrm{ZnSO}_{4} 1.200$ & 27.6 \\
\hline & & $\mathrm{ZnSO}_{4} 1.470$ & $14.2 *$ & & & $\mathrm{ZnSO}_{4} 1.470$ & $47.2 *$ \\
\hline
\end{tabular}

*highest sensitivity for the culture type

- Investigation of the sensitivity of the methods through soil medium
In testing the sensitivity of the two methods by soil medium, with a culture concentration of 500 eggs or oocysts $/ \mathrm{ml}$, the results are shown in Table 3. 
IVANOV A., et al.

Table 3. Investigation of the sensitivity of the methods through soil medium (in cultures with 500 eggs or oocysts $/ \mathrm{ml}$ )

\begin{tabular}{|c|c|c|c|c|c|c|c|}
\hline ᄅ⿱艹 & $\begin{array}{l}\text { Culture } \\
\text { of eggs or } \\
\text { oocysts }\end{array}$ & $\begin{array}{l}\text { Flotation } \\
\text { solution and } \\
\text { relative } \\
\text { density }\end{array}$ & $\begin{array}{l}\text { Sensitivity } \\
\text { in } \%\end{array}$ & 莺 & $\begin{array}{l}\text { Culture } \\
\text { of eggs or } \\
\text { oocysts }\end{array}$ & $\begin{array}{l}\text { Flotation } \\
\text { solution and } \\
\text { relative } \\
\text { density }\end{array}$ & $\begin{array}{l}\text { Sensitivity } \\
\text { in \% }\end{array}$ \\
\hline \multirow{16}{*}{ 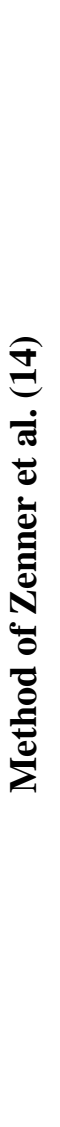 } & \multirow{4}{*}{$\begin{array}{c}\text { Toxocara } \\
\text { canis }\end{array}$} & $\mathrm{NaCl} 1.200$ & 0.6 & \multirow{16}{*}{ 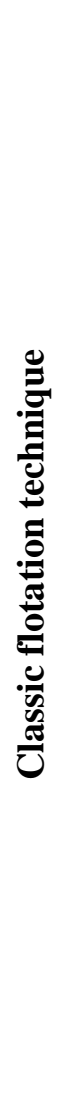 } & \multirow{4}{*}{$\begin{array}{c}\text { Toxocara } \\
\text { canis }\end{array}$} & $\mathrm{NaCl} 1.200$ & 1.6 \\
\hline & & $\mathrm{MgSO}_{4} 1.300$ & $4^{*}$ & & & $\mathrm{MgSO}_{4} 1.300$ & 8 \\
\hline & & $\mathrm{ZnSO}_{4} 1.200$ & 0.6 & & & $\mathrm{ZnSO}_{4} 1.200$ & 0.8 \\
\hline & & $\mathrm{ZnSO}_{4} 1.470$ & 1.4 & & & $\mathrm{ZnSO}_{4} 1.470$ & $16.4 *$ \\
\hline & \multirow{4}{*}{$\begin{array}{c}\text { Trichuris } \\
\text { vulpis }\end{array}$} & $\mathrm{NaCl} 1.200$ & 0.2 & & \multirow{4}{*}{$\begin{array}{c}\text { Trichuris } \\
\text { vulpis }\end{array}$} & $\mathrm{NaCl} 1.200$ & 0.1 \\
\hline & & $\mathrm{MgSO}_{4} 1.300$ & 0.8 & & & $\mathrm{MgSO}_{4} 1.300$ & $1.6^{*}$ \\
\hline & & $\mathrm{ZnSO}_{4} 1.200$ & 0.2 & & & $\mathrm{ZnSO}_{4} 1.200$ & 0.1 \\
\hline & & $\mathrm{ZnSO}_{4} 1.470$ & $1.2 *$ & & & $\mathrm{ZnSO}_{4} 1.470$ & $1.6^{*}$ \\
\hline & \multirow{4}{*}{$\begin{array}{c}\text { Taenia } \\
\text { pisiformis }\end{array}$} & $\mathrm{NaCl} 1.200$ & 0.4 & & \multirow{4}{*}{$\begin{array}{c}\text { Taenia } \\
\text { pisiformis }\end{array}$} & $\mathrm{NaCl} 1.200$ & $0 !$ \\
\hline & & $\mathrm{MgSO}_{4} 1.300$ & 0.1 & & & $\mathrm{MgSO}_{4} 1.300$ & $\mathbf{0 !}$ \\
\hline & & $\mathrm{ZnSO}_{4} 1.200$ & 0.1 & & & $\mathrm{ZnSO}_{4} 1.200$ & $\mathbf{0 !}$ \\
\hline & & $\mathrm{ZnSO}_{4} 1.470$ & $2.6^{*}$ & & & $\mathrm{ZnSO}_{4} 1.470$ & $\mathbf{0 !}$ \\
\hline & \multirow{4}{*}{$\begin{array}{c}\text { Eimeria } \\
\text { stiedai }\end{array}$} & $\mathrm{NaCl} 1.200$ & 3 & & \multirow{4}{*}{$\begin{array}{c}\text { Eimeria } \\
\text { stiedai }\end{array}$} & $\mathrm{NaCl} 1.200$ & $\mathbf{0 !}$ \\
\hline & & $\mathrm{MgSO}_{4} 1.300$ & 2.8 & & & $\mathrm{MgSO}_{4} 1.300$ & $\mathbf{0 !}$ \\
\hline & & $\mathrm{ZnSO}_{4} 1.200$ & 4 & & & $\mathrm{ZnSO}_{4} 1.200$ & $0 !$ \\
\hline & & $\mathrm{ZnSO}_{4} 1.470$ & $7 *$ & & & $\mathrm{ZnSO}_{4} 1.470$ & $\mathbf{0 !}$ \\
\hline
\end{tabular}

*highest sensitivity for the culture type

For T. canis egg culture, the highest sensitivity according to the method of Zenner et al. (14) was obtained when working with the $\mathrm{MgSO}_{4}$ flotation solution (RD 1.300) - 4\%. Low sensitivity was found with the flotation solution of $\mathrm{ZnSO}_{4}$ (RD 1.470) - $1.4 \%$, and lower sensitivity was observed with $\mathrm{ZnSO} 4$ (RD 1.200) - $0.6 \%$ and $\mathrm{NaCl}$ (RD 1.200) $0.6 \%$.

In the study of the same culture using the classic flotation technique, the highest sensitivity was obtained when working with the $\mathrm{ZnSO}_{4}$ flotation solution (RD 1.470) $16.4 \%$. We found a low sensitivity of the $\mathrm{MgSO}_{4}$ flotation solution (RD 1.300) - 8\%, and lower sensitivity of $\mathrm{ZnSO}_{4}$ (RD 1.200) $0.8 \%$ and $\mathrm{NaCl}$ (RD 1.200) - $1.6 \%$.

For the culture of $T$. vulpis eggs, the highest sensitivity according to the method of Zenner et al. (14) was obtained when working with the
$\mathrm{ZnSO}_{4}$ flotation solution (RD 1.470) - 1.2\% Low sensitivity was found with the flotation solution of $\mathrm{MgSO}_{4}$ (RD 1.300) - $0.8 \%$, and lower sensitivity of $\mathrm{ZnSO}_{4}$ (RD 1.200) - $0.2 \%$ and $\mathrm{NaCl}$ (RD 1.200) - $0.2 \%$.

In the study of the same culture using the classic flotation technique, the highest sensitivity was obtained when working with flotation solutions of $\mathrm{ZnSO}_{4}$ (RD 1.470) and $\mathrm{MgSO}_{4}(\mathrm{RD} 1.300)-1.6 \%$, and low sensitivity of $\mathrm{ZnSO}_{4}$ (RD 1.200) and $\mathrm{NaCl}(\mathrm{RD} \mathrm{1,200)} \mathrm{-}$ $0.1 \%$.

For the $T$. pisiformis egg culture, the highest sensitivity according to the method of Zenner et al. (14) was obtained when working with the $\mathrm{ZnSO}_{4}$ flotation solution (RD 1.470) - 2.6\%. We found low sensitivity of $\mathrm{ZnSO}_{4}$ (RD 1.200) - $0.1 \%, \mathrm{MgSO}_{4}$ (RD 1.300) - $0.1 \%$ and $\mathrm{NaCl}$ (RD 1.200) - $0.4 \%$. 
In the study of the same culture using the classic flotation technique, we could not calculate the sensitivity of the solutions, because mixing the soil medium with the flotation solution produced a lot of foam, which prevent discovering Taenia spp. eggs.

For the culture with E. stiedai oocysts, the highest sensitivity according to the method of Zenner et al. (14) was obtained when working with the $\mathrm{ZnSO}_{4}$ flotation solution (RD 1.470) $7 \%$. Low sensitivity was found for the flotation solution of $\mathrm{ZnSO}_{4}$ (RD 1.200) - 4\%, and the similarity was found for the sensitivity of
$\mathrm{MgSO}_{4}(\mathrm{RD} 1.300)-2.8 \%$ and $\mathrm{NaCl}$ (RD 1.200) - 3\%.

- Investigation of the sensitivity of selected methods for the examination of naturally contaminated samples

50 soil or sand samples from the town of Stara Zagora were examined by the modified method of Zenner et al. (14) and the classical flotation technique using a flotation solution of $\mathrm{ZnSO}_{4}$ with RD 1.470. The results obtained are presented in Table 4 and Table 5.

Table 4. Investigation of soil and sand samples from the town of Stara Zagora

\begin{tabular}{|c|c|c|}
\hline Methods & Number of samples & $\begin{array}{c}\text { Number of positive to the total } \\
\text { number and \% }\end{array}$ \\
\hline $\begin{array}{c}\text { Modified method of Zenner } \\
\text { et al. (14) }\end{array}$ & 50 & $26 / 52$ \\
\hline $\begin{array}{c}\text { Classic flotation } \\
\text { technique }\end{array}$ & 50 & $19 / 38$ \\
\hline
\end{tabular}

Table 5. Established parasitic eggs and sporocysts in soil and sand samples from the town of Stara Zagora

\begin{tabular}{|l|c|c|c|c|}
\hline \multirow{2}{*}{ Parasitic species } & $\begin{array}{c}\text { Modified method of Zenner } \\
\text { et al. (14) }\end{array}$ & \multicolumn{2}{c|}{$\begin{array}{c}\text { Classic flotation } \\
\text { technique }\end{array}$} \\
\cline { 2 - 5 } & \multicolumn{3}{|c|}{ Total samples, N=50 } \\
\cline { 2 - 5 } & $\begin{array}{c}\text { Number of } \\
\text { positive samples }\end{array}$ & $\%$ & $\begin{array}{c}\text { Number of } \\
\text { positive samples }\end{array}$ & $\%$ \\
\hline Toxocara spp. & 15 & 30.0 & 18 & 36.0 \\
\hline Toxascaris leonina & 2 & 4.0 & 3 & 6.0 \\
\hline Ancylostoma spp. & 2 & 4.0 & 2 & 4.0 \\
\hline Uncinaria spp. & 1 & 2.0 & 1 & 2.0 \\
\hline Trichuris spp. & 2 & 4.0 & 3 & 6.0 \\
\hline Taenia spp. & 3 & 6.0 & 0 & 0 \\
\hline Sarcocystis spp. & 4 & 8.0 & 0 & 0 \\
\hline Total positive samples & 29 & 58.0 & 27 & 54.0 \\
\hline
\end{tabular}

\section{DISCUSSION}

- Investigation of the sensitivity of the methods directly and through a standard medium

The values found by the two types of techniques tested with solutions of different relative densities__ (RD) for detecting developmental stages of parasites directly and in the standard medium showed that the methods using solutions with higher RD (for the modified method of Zenner et al. (14), these are the solution of $\mathrm{MgSO}_{4}$ with RD of 1.300 and the solution of $\mathrm{ZnSO}_{4}$ with $\mathrm{RD}$ of
1.470, and for the classic flotation technique only the solution of $\mathrm{ZnSO}_{4}$ with RD of 1.470), are more sensitive. However, a comparison of the two methods clearly demonstrates the much higher efficiency of the classic technique, which is 4-5 times more sensitive than the modified method of Zenner et al. (14). Similar comparative studies are performed by Quinn et al. (5), Zenner et al. (14), Santarem et al. (12), Gnani et al. (15) which compared other methods and solutions but also reported higher sensitivity of methods using solutions with higher relative density. An interesting fact 
is the higher sensitivity of the classic technique observed by us. We have not found such comparative studies in the scientific literature. Our assumptions for the observed phenomenon are that in the classic flotation technique opencone vessels are used which do not impede the emergence of parasitic eggs and oocysts compared to cylindrical tubes used in the method of Zenner et al. (14) which will prevent the parasitic forms touching the walls of the vessel.

When comparing the two test methods, we performed the techniques after single centrifugation or flotation to perform the procedure under the same conditions. In many embodiments, multiple centrifugation and microscopy are recommended to increase the efficiency rate $(5,12,14,15)$.

- Investigation of the sensitivity of the methods by soil medium

In the study of the two methods by soil medium, as shown in the tables, we obtained different and contradictory results. Again, the highest sensitivity was reported in the modified method of Zenner et al. (14), as found by other authors, which is easily explained by the larger flotation forces of the solutions $(5,12,15)$. However, in the classic technique, after mixing the flotation medium with the soil, foam was obtained which made microscopic examination difficult. In microscopy, we were able to detect, although difficult, the eggs of $T$. canis and $T$. vulpis, perhaps because of their specific morphology, but the eggs of $T$. pisiformis and the oocysts of E. stiedai were extremely difficult to differentiate among the many foamforming air bubbles. Probably these bubbles are formed due to the content of some surfactants in the soil. Their appearance is clearly prevented by using centrifugation, as in the method of Zenner et al. (14) or by repeatedly washing the soil before flotation recommended by Gnani et al. (15). However, it should be noted that the detection of eggs of $T$. canis and T. vulpis in classic technique, despite the difficulties, showed better results.

For the reasons listed above, we decided to apply the two methods with a solution of $\mathrm{ZnSO}_{4}$ with a relative density of 1.470 in the study of the soil samples taken from the town of Stara Zagora.

- Investigation of the sensitivity of selected methods for the examination of naturally contaminated samples

Considering the results of studies of naturally contaminated soil samples, the benefit of the modified method of Zenner et al. (14) which detects a higher percentage of positive samples and more types of eggs and oocysts, is clear. During the cultivation of naturally contaminated soils, foam formation reappeared, making microscopy difficult. Apparently, pre-washing with water and subsequent centrifugation prevent or significantly reduce the possibility of air bubbles.

On the other hand, the results of the study of soil samples from the city of Stara Zagora indicate that the urban environment is contaminated with dangerous parasitic eggs and oocysts, which can cause serious health consequences for citizens. Of particular concern is the presence of Taenia spp. eggs, but also Ancylostoma sp. and Toxocara eggs.

\section{CONCLUSION}

In case of soil testing from different populated and unpopulated regions for contamination with parasitic eggs and oocysts, the modified method of Zenner et al. (2002) with a solution of $\mathrm{ZnSO}_{4}$ with a relative density of 1.470 may be used.

There are areas of the environment in the town of Stara Zagora that are contaminated with dangerous parasitic eggs and oocysts.

\section{REFERENCES}

1. Brooker, S., Clements, A., Bundy, D., Global epidemiology, ecology and control of soil transmitted infections. $A d v$ Parasitol, 62:221-261, 2006.

2. Kamburov, P., Vasilev, I., Georgieva, D., Kamenov, Y., Koinarski, V., Veterinary parasitology. Agropres, Sofia, 1994.

3. Bowman, D. D., Georgis' parasitology for veterinarians $8^{\text {th }}$ edition. Sauders, Philadelphia, USA, pp. 430, 1999.

4. Dada, B. J. O., A new technique for the recovery of Toxocara eggs from soil. $J$ Helminthol, 53:141-144, 1979.

5. Quinn, R., Smith, H. V., Bruce, R. G., Girdwood, R. W. A., Studies on the incidence of Toxocara and Toxascaris spp. ova in the environment. I. A comparison of flotation procedures for recovery of Toxocara spp. ova from soil. J Hyg (Lond), 84:83-89, 1980.

6. Kazakos, K., Improved method for recovering ascarids and other helminth eggs from soil associated with epizootics and 
during survey studies. Am J Vet Res, 44:896-900, 1983.

7. Oge, H., Oge, S., Quantitative comparison of various methods for detecting eggs of Toxocara canis in samples of sand. Vet Parasitol, 92:75-79, 2000.

8. Dunsmore, J. D., Thompson, R. C. A., Bates, I. A., Prevalence and survival of Toxocara canis eggs in the urban environment of Perth Australia. Vet Parasitol, 16:303-311, 1984.

9. O'Lorcain, P., Prevalence of Toxocara canis ova in public playgrounds in the Dublin area of Ireland. J Helminthol, 68:237-241, 1994.

10.Ferre, P., Dorchies, Ph., Recherche des oefs de Toxocara dans le sable des aires de jeux de huit jardins publics. Revue Med Vet, 151, 6:501-506, 2000.

11.Grover, R., Bhatti, G., Aggarwal, A., Malla, N., Isolation of Toxocara eggs in and
IVANOV A., et al.

around Chandigah, India. J Parasit Dis, 24:57-59, 2000.

12.Santarem, V. A., Magoti, L. P., Sichieri, T. D., Influence of variables on centrifugeflotation technique for recovery of Toxocara canis eggs from soil. Rev Inst Med Trop S Paolo, 51, 3:163-167, 2009.

13.Das, S. S., Kumar, D., Sreekrishnan, R., Ganesan, R., Soil contamination of public places, playgrounds and residential areas with ova of Toxocara in Puducherry city. $J$ Vet Res, 17:13-16, 2009.

14.Zenner, L., Gounel, J. M., Chauve, C. M., A standardized method for detecting parasite eggs and oocysts in soils. Revue Med Vet, 153, 11:729-734, 2002.

15.Gnani Charitha, V., Rayulu, V. C., Konddaiah, P., Srilatha, Ch., Comparative evaluation of flotation techniques for the detection of soil borne parasites. J Parasit Dis, 37, 2:260-263, 2013. 